\title{
108. Ontogenetic Development of Blood Group Substances in Embryos and Newborns. I. A.B.O Group Substances
}

By Tanemoto FuruhaTA, M.J.A., Takeo IIDA, and Toshiyuki SEKI

Department of Legal Medicine, Tokyo Medical and Dental University

(Comm. June 12, 1954)

\section{Introduction}

The first communication on the analysis of partial antigens in the blood type substances was made by Mizutani (1932) ${ }^{1)}$ and Yamazaki $(1932)^{2}$ in their reports on the structure of the B-type substance. Following these, studies have been made on this subject by Friedenreich (1933), Dahr and Lindau (1937), ${ }^{3)}$ Hirota, ${ }^{4)}$ Murakami, ${ }^{\text {5) }}$ Sakuma, ${ }^{6)}$ Kobayashi, ${ }^{72}$ and Yamaguchi $^{8)}$ and on the basis of their results, the B-type substance is differentiated into $B_{I}, B_{I I}$ and $B_{I I I .}{ }^{9)}$

Schiff and Adelsberger $(1924)^{10)}$ found the existence of A antigen in sheep blood cells and Mizu (1931) $)^{11)}$ in pig blood cells and Terajima $(1942)^{12}$ studied the A-type substance in dog blood cells. Brockmann (1911) ${ }^{13)}$ reported on the existence of a substance in dog blood cells that absorbes the anti-A agglutinin. Terajima made a comparative analysis of the A-type substance in various animals and succeeded to differentiate the partial antigens of this substance into $A_{I}, A_{I I}, A_{I I I}$ and $A_{I V}$.

The O-type substance was found by Inouye $(1943)^{14)}$ to consist of $\mathrm{O}_{\mathrm{I}}, \mathrm{O}_{\mathrm{II}}$ and $\mathrm{O}_{\mathrm{III}}$. Akimitsu $(1942)^{1 \mathrm{15})}$ fractionated this substance into carbohydrate, lipoid and protein.

Ino $(1950)^{16)}$ measured the degrees of development of the partial antigens of A-, B- and O-type substances in the embryonic blood cells at various stages of development. We reinvestigated the results of Ino, and some of the interesting results which we have obtained from these studies shall be communicated here.

\section{Experimental}

1. Method of preparation of partial antibodies

A) Anti-A partial antibodies

1) Anti- $A_{I}$ agglutinin

$5 \mathrm{cc}$ of the saline suspension of the human A-type blood cells in the concentration of $10 \%$ was injected into the conch vein of the $\mathrm{A}^{(-)}$type rabbits (non-secretors of the A blood substance) from six to seven times at intervals of three days. The animals were sac- 
rificed seven days after the last injection and the serum was taken. It was then inactivated by heating at $56^{\circ} \mathrm{C}$ for thirty minutes and after addition of carbonic acid in the concentration of $0.5 \%$, it was kept in an ice-box. At the time of the experiments, the serum was treated with the O-type and B-type human blood cells to remove the heteroagglutinin and it was then treated further with A-type dog blood cells, whereby the anti- $\mathrm{A}_{I I}$, Anti- $\mathrm{A}_{\mathrm{III}}$ and anti- $\mathrm{A}_{\mathrm{IV}}$ agglutinins were absorbed away, leaving a pure anti- $A_{I}$ agglutinin.

2) Anti- $A_{\text {II }}$ agglutinin

By means of the same procedure, $A^{(-)}$type rabbits were immunized against $A$-type $\operatorname{dog}$ blood cells $\left(A_{I I} \cdot A_{I I} \cdot A_{I V}\right)$ and the serum obtained from the rabbits was treated first with O-type and B-type human blood cells for the removal of the heteroagglutinin and then with the A-type pig blood cells to remove the anti- $A_{\text {III }}$ and anti- $A_{I V}$ agglutinins. A pure anti- $\mathrm{A}_{\text {II }}$ agglutinin was thus prepared.

3) Anti-A $A_{\text {IIr }}$ agglutinin

Similarly, the serum obtained from $\mathrm{A}^{(-)}$type rabbits immunized against A-type pig blood cells $\left(\mathrm{A}_{\mathrm{III}} \cdot \mathrm{A}_{\mathrm{IV}}\right)$ was treated with O-type and B-type human blood cells whereby the heteroagglutinin was removed. It was then purified for the anti- $A_{I I I}$ agglutinin by absorbing away the anti- $A_{I V}$ agglutinin with blood cells $\left(A_{I V}\right)$ of the sheep of the non-secretor type for the A-type substance.

4) Anti-A $A_{I V}$ agglutinin

$\mathrm{A}^{(-)}$type rabbits were immunized against the blood cells of sheep not secreting the A-type substance in the saliva. The serum from the immunized rabbits was made pure for the Anti- $\mathrm{A}_{\mathrm{Ir}}$ agglutinin by removing the heteroagglutinin with O-type and B-type human blood cells.

B) Anti-B partial antibodies

1) Anti- $B_{I}$ agglutinin

$5 \mathrm{cc}$ of the saline suspension of the human B-type blood cells in the concentration of $10 \%$ was injected into the vein of fowls from six to seven times at intervals of three days. The procedure was exactly the same as the previous cases. At the time of experiments, the serum was treated with the O-type and A-type human blood cells to remove the heteroagglutinin and it was then treated further with rabbit blood cells whereby the anti- $B_{\text {II }}$ and anti- $B_{\text {III }}$ agglutinins were absorbed away, leaving pure anti- $\mathrm{B}_{\mathrm{I}}$ agglutinin.

2) Anti-B $B_{\text {II }}$ agglutinin

By means of the same procedure, fowls were immunized against rabbit blood cells $\left(\mathrm{B}_{\mathrm{II}} \cdot \mathrm{B}_{\mathrm{III}}\right)$ and the serum obtained from the fowls was treated first with O-type and A-type human blood cells for the 
removal of the heteroagglutinin and then with the guinea-pig blood cells to remove the anti- $\mathrm{B}_{\text {III }}$ agglutinin. A pure anti- $\mathrm{B}_{\text {II }}$ agglutinin was thus prepared.

3) Anti- $B_{\text {III }}$ agglutinin

Similarly, the serum obtained from fowls immunized against guinea-pig blood cells $\left(\mathrm{B}_{\mathrm{III}}\right)$ was treated with O-type and B-type human blood cells whereby the heteroagglutinin was removed.

C) Anti-O partial antibodies

1) Anti- $\mathrm{O}_{\mathrm{I}}$ agglutinin

$5 \mathrm{cc}$ of the saline suspension of the human O-type blood cells in the concentration of $10 \%$ was injected into the vein of fowls. At the time of experiments, the serum was treated with the ABe-type human blood cells to remove the heteroagglutinin, normal anti-A and anti-B agglutinins and it was then treated further with rat blood cells whereby the anti- $\mathrm{O}_{\text {II }}$ and anti- $\mathrm{O}_{\text {III }}$ agglutinins were absorbed away.

2) Anti- $\mathrm{O}_{\text {II }}$ agglutinin

By means of the same procedure, fowls were immunized against rat blood cells and the serum obtained from the fowl was treated with ABe-type human blood cells for removal of the unnecessary agglutinin and then with the rabbit blood cells to remove the anti$\mathrm{O}_{\text {III }}$ agglutinin.

3) Anti- $\mathrm{O}_{\text {III }}$ agglutinin

Similarly, the serum obtained from fowl immunized against rabbit blood cells $\left(\mathrm{O}_{\mathrm{III}}\right)$ was treated with ABe-type human blood cells whereby the unnecessary agglutinin was removed.

2. Examination of agglutination

Agglutination reactions were observed in depression slides. The standard serum was diluted in series, $\frac{1}{2}, \frac{1}{4}, \frac{1}{8}$ and so on and to a drop of each was added a drop of 1\% blood cell suspension to be tested. Examination was made after thirty minutes of standing at room temperature. The strength of reaction was designated by $(H),(+),(+),( \pm)$ and $(-)$, last one being the indication of negative reaction.

3. Experimental materials

We used the blood cells of foetuses, newborn babies, infants and adult men. It was difficult to obtain blood cells from early embryonal period, especially 2-3 months. When complete foetus bodies were obtained they were washed several times with salinesolution, and homogenized. When the foetal bodies were not intact, the liver was taken and homogenized.

After embryonal 5 months, we used the navel blood at parturition. In order to make certain that the foetal blood and mother 
blood are not mixed, the latter was taken and compared with the navel blood.

4. Method of designation of agglutinogen strength

The method by Kemp and Worsaae ${ }^{17)}$ was used for the comparison of agglutinogen strength. Men having agglutination reaction of the standard strength were selected and the strength of their agglutinogen was designated as 100. If an anti-serum, which can agglutinate these standard blood cells up to the dilution of $\frac{1}{16}$, does agglutinate blood cells of unknown strength up to $\frac{1}{8}$, the agglutinogen of these blood cells is said to be of the strength of $50 \%$. Table I illustrates the method of designation of agglutinogen strength.

Table I

The numerical designation of agglutinogen strength

\begin{tabular}{|c|c|c|c|c|c|c|c|c|c|c|}
\hline $\begin{array}{l}\text { Serum dilu- } \\
\text { tion } \\
\text { Red cells }\end{array}$ & $\frac{1}{1}$ & $\frac{1}{2}$ & $\frac{1}{4}$ & $\frac{1}{8}$ & $\begin{array}{c}1 \\
16\end{array}$ & $\frac{1}{32}$ & $\frac{1}{64}$ & $\frac{1}{128}$ & $\frac{1}{256}$ & Strength \\
\hline $\begin{array}{ll}\text { No. } & 4 \\
\text { No. } & 3 \\
\text { No. } & 2 \\
\text { No. } & 1\end{array}$ & $\begin{array}{l}+ \\
+ \\
+ \\
+\end{array}$ & $\begin{array}{l}+ \\
+ \\
+ \\
+\end{array}$ & $\begin{array}{l}+ \\
+ \\
+ \\
+\end{array}$ & $\begin{array}{l}+ \\
+ \\
+ \\
+\end{array}$ & $\begin{array}{l}+ \\
+ \\
+ \\
+\end{array}$ & $\begin{array}{l}+ \\
+ \\
+ \\
\pm\end{array}$ & $\begin{array}{l} \pm \\
\pm\end{array}$ & - & - & $\begin{array}{l}400 \\
300 \\
200 \\
150\end{array}$ \\
\hline Standard cells & + & + & + & + & + & & & & & 100 \\
\hline $\begin{array}{lr}\text { No. } & 1 \\
\text { No. } & 2 \\
\text { No. } & 3 \\
\text { No. } & 4 \\
\text { No. } & 5 \\
\text { No. } & 6 \\
\text { No. } & 7 \\
\text { No. } & 8 \\
\text { No. } & 9 \\
\text { No. } 10\end{array}$ & $\begin{array}{l}+ \\
+ \\
+ \\
+ \\
+ \\
+ \\
+ \\
+ \\
+\end{array}$ & $\begin{array}{l}+ \\
+ \\
+ \\
+ \\
+ \\
+ \\
\pm\end{array}$ & $\begin{array}{l}+ \\
+ \\
+ \\
+ \\
\pm\end{array}$ & $\begin{array}{l}+ \\
+ \\
\pm\end{array}$ & \pm & & & & & $\begin{array}{l}75 \\
50 \\
37.5 \\
25.0 \\
18.7 \\
12.5 \\
9.4 \\
6.3 \\
4.8 \\
0\end{array}$ \\
\hline
\end{tabular}

\section{Experimental Results}

1. The A-type substance

The strengths of the agglutinogen in foetuses, newborns and infants at each period are presented in Table II. As readily seen in the table, at the earliest period of foetal development, while $A_{I}$ is at the average value of 3.0, the lower parts, $A_{I I}, A_{I I I}$ and $A_{I V}$ are respectively $7.2,9.0$ and 14.2 which are in the ascending order from the higher to the lower parts. During the first half of the foetal life, this relation is predominant, but during the latter half, the development of $A_{I}$ and $A_{I I}$ parts tend to be relatively greater than $A_{I I I}$ and $A_{I V}$ and the strengths of the four parts become very close to each other at about eighth foetal month. This relation is indicated in Fig. 1. As the figure shows, at the time of parturition, the strength of the agglutinogen is approximately $60 \%$ 


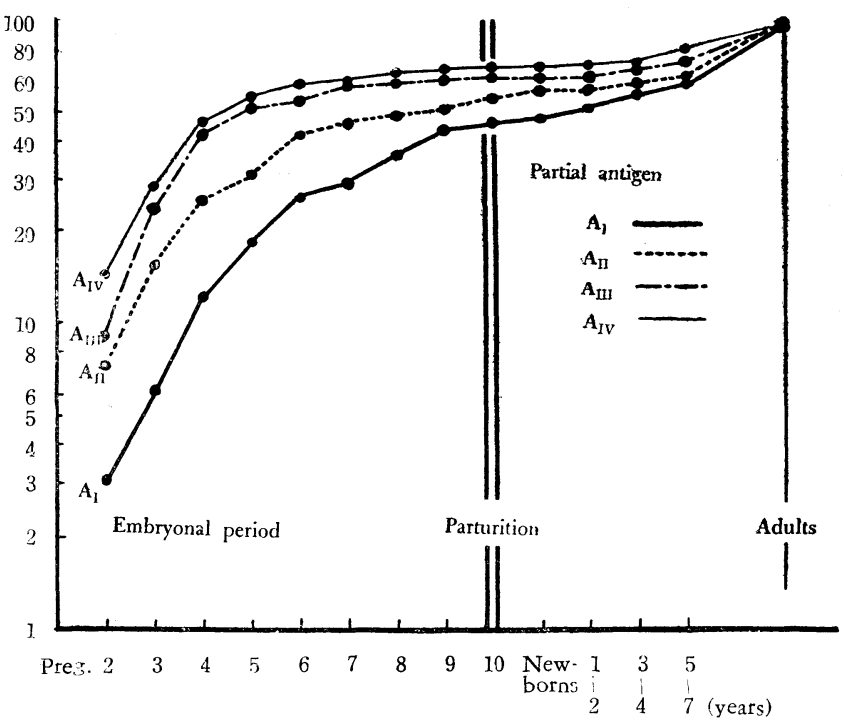

Fig. 1. Ontogenetic development of A-group substance

Table II

Strength of A-group substance at various periods

\begin{tabular}{|c|c|c|c|c|c|c|c|c|}
\hline $\begin{array}{l}\begin{array}{c}\text { Partial } \\
\text { antigen }\end{array} \\
\text { Periods }\end{array}$ & $\mathrm{A}_{\mathrm{I}}$ & $\mathrm{A}_{\text {II }}$ & $\mathrm{A}_{\text {III }}$ & $\mathrm{A}_{\mathrm{IV}}$ & $\begin{array}{c}\text { Partial } \\
\text { antigen } \\
\text { Periods }\end{array}$ & $\mathrm{B}_{\mathrm{I}}$ & $\mathbf{B}_{\mathrm{II}}$ & $\mathrm{B}_{\mathrm{III}}$ \\
\hline $\begin{array}{r}\text { Preg. } \\
3 \\
4 \\
5 \\
6 \\
7 \\
8 \\
9 \\
10\end{array}$ & $\begin{array}{r}3.0 \\
6.1 \\
12.3 \\
18.6 \\
26.0 \\
29.8 \\
37.9 \\
44.0 \\
46.9\end{array}$ & $\begin{array}{r}7.2 \\
15.5 \\
25.3 \\
31.7 \\
42.0 \\
46.4 \\
48.6 \\
51.2 \\
56.1\end{array}$ & $\begin{array}{r}9.0 \\
24.2 \\
42.0 \\
51.6 \\
54.9 \\
60.1 \\
60.9 \\
63.7 \\
65.9\end{array}$ & $\begin{array}{l}14.2 \\
28.9 \\
46.0 \\
54.1 \\
61.2 \\
60.8 \\
67.9 \\
69.6 \\
70.0\end{array}$ & $\begin{array}{r}\text { Preg. } \\
3 \\
4 \\
5 \\
6 \\
7 \\
8 \\
9 \\
10\end{array}$ & $\begin{array}{r}5.0 \\
6.0 \\
11.1 \\
17.0 \\
23.5 \\
30.2 \\
38.3 \\
44.0 \\
50.1\end{array}$ & $\begin{array}{l}13.4 \\
22.6 \\
27.2 \\
34.8 \\
42.0 \\
49.9 \\
51.2 \\
56.0 \\
58.3\end{array}$ & $\begin{array}{l}17.9 \\
35.5 \\
42.6 \\
49.3 \\
55.2 \\
61.3 \\
62.1 \\
65.5 \\
63.7\end{array}$ \\
\hline $\begin{array}{l}\text { Newborns } \\
1-2 \text { years } \\
3-4 \text { years } \\
5-7 \text { years }\end{array}$ & $\begin{array}{l}47.1 \\
51.7 \\
58.3 \\
62.4\end{array}$ & $\begin{array}{l}59.8 \\
59.7 \\
62.3 \\
64.1\end{array}$ & $\begin{array}{l}64.1 \\
66.2 \\
68.3 \\
73.3\end{array}$ & $\begin{array}{l}70.3 \\
70.5 \\
70.8 \\
83.2\end{array}$ & $\begin{array}{l}\text { Newborns } \\
1-2 \text { years } \\
3-4 \text { years } \\
5-7 \text { years }\end{array}$ & $\begin{array}{l}56.4 \\
59.9 \\
68.2 \\
78.5\end{array}$ & $\begin{array}{l}64.2 \\
69.5 \\
72.1 \\
83.5\end{array}$ & $\begin{array}{l}69.8 \\
72.3 \\
76.7 \\
88.9\end{array}$ \\
\hline Adults & 96.3 & 97.2 & 97.8 & 96.0 & Adults & 93.7 & 94.6 & 96.4 \\
\hline
\end{tabular}

Table III

Strength of B-group substance at various periods

of the adult strength, but the development of the strength proceeds thereafter, reaching closely the adult value at about 5-7 years of age. It is to be pointed out further that the relative strengths of the partial antigens remain to be in the order of $A_{I V}>A_{I I I}>A_{I I}$ $>\mathrm{A}_{\mathrm{I}}$ at each period.

2. The B-type substance

As shown in Table III, the B-type substance develops in the manner similar to the A-type substance. At the second foetal 
month, $B_{I}$ is 5.0 while $B_{I I}$ and $B_{I I}$ are respectively 13.4 and 17.9, indicating a relatively greater development of the lower parts. The comparison of the ratio between $B_{I}$ and $B_{I I}$ and that between $B_{I I}$ and $B_{I I I}$ shows a striking closeness of $B_{I I}$ and $B_{I I I}$ values. Furthermore, whereas $B_{I I}$ and $B_{\Pi I}$ are already well developed during the first half of the foetal life, $\mathrm{B}_{\mathrm{I}}$ is only poorly developed. Later at about eighth month, $B_{I}, B_{I I}$ and $B_{\mathrm{II}}$ all show a good development. At the time of parturition, the strength of B-agglutinogen in the

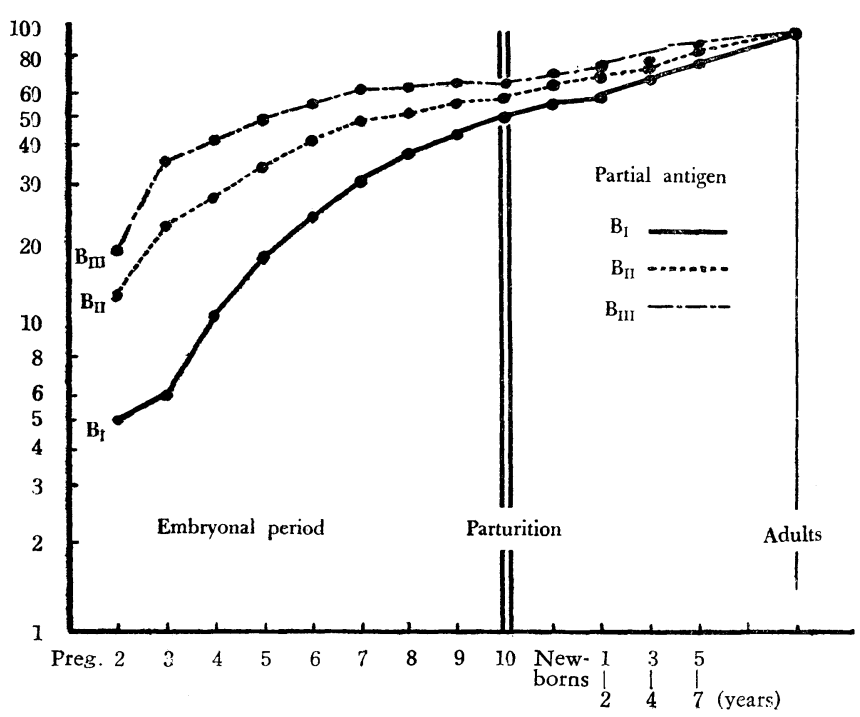

Fig. 2. Ontogenetic development of B-group substance

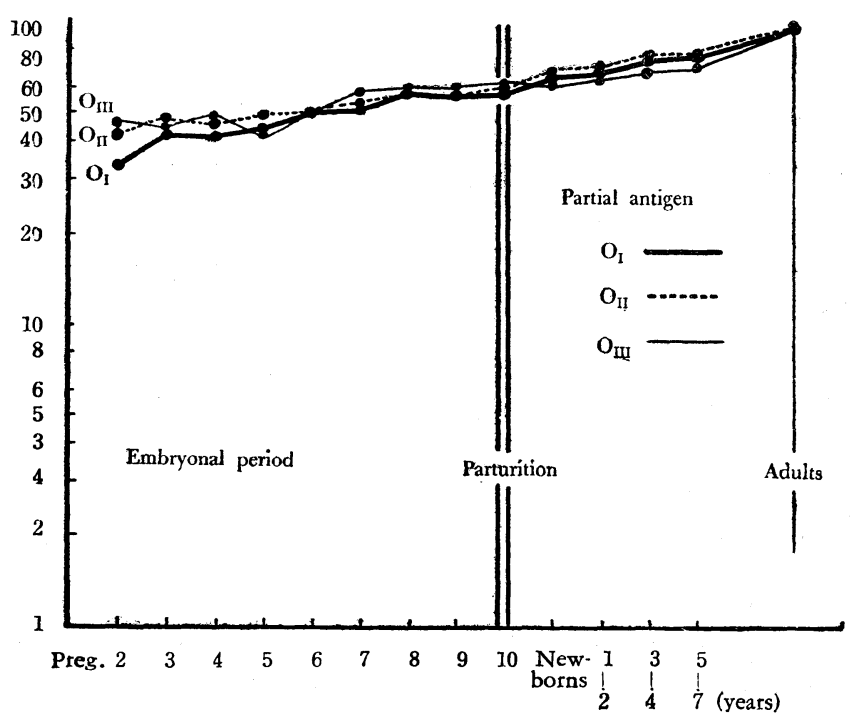

Fig. 3. Ontogenetic development of O-group substance 
foetal blood cells is about $50-64 \%$ of the adult value (taken as 100). In general, the development proceeds gradually, maintaining the relation, $B_{I I I}>B_{I I}>B_{I}$, and approaches closely the adult value at about five years after birth. These results are shown in Fig. 2.

3. The O-type substance

As shown in Table IV, the O-type substance is different in development from both A- and B-type substances; it is already very well developed at the first half of the foetal life (34.2-45.0 at the second foetal month) and continues to develop slowly then on till

Table IV

Strength of O-group substance at various periods

\begin{tabular}{c|c|c|c}
\hline $\begin{array}{c}\text { Partial } \\
\text { antigen }\end{array}$ & OI & O & OII \\
Periods & & & \\
\hline Preg. 2 & 34.2 & 42.3 & 45.0 \\
3 & 42.8 & 47.6 & 43.2 \\
4 & 42.1 & 45.8 & 47.7 \\
5 & 44.6 & 49.3 & 43.6 \\
6 & 50.0 & 50.1 & 50.4 \\
7 & 50.4 & 52.3 & 59.1 \\
8 & 58.9 & 58.6 & 60.0 \\
9 & 57.0 & 57.6 & 60.0 \\
10 & 58.9 & 60.0 & 64.7 \\
\hline Newborns & 65.5 & 68.3 & 63.5 \\
$1-2$ years & 69.3 & 72.7 & 64.9 \\
3-4 years & 75.5 & 77.4 & 69.3 \\
5-7 years & 77.2 & 79.9 & 70.0 \\
\hline \hline Adults & 94.0 & 98.0 & 98.6 \\
\hline A
\end{tabular}

its value reaches approximately $60 \%$ of the adult value at parturition. The development proceeds thereafter and comes very closely to the adult value at about 5-7 years of age as in the case of $\mathrm{A}$ and B-type substances. The O-type substance is, however, different from the other two in that the relation, $\mathrm{O}_{\mathrm{II}}>\mathrm{O}_{\mathrm{II}}>\mathrm{O}_{\mathrm{I}}$, is not found; the higher part may show a higher value than the lower part at times while the lower part may be greater in value than the higher part at other times, having no consistent relationship. This situation is indicated in Fig. 3.

\section{Summary and Conclusion}

From the results of our studies presented thus far in details, we may tabulate the essential facts and draw our conclusion. With respect to $\mathrm{A} \cdot \mathrm{B} \cdot \mathrm{O}$ blood types, the following points are to be reemphasized :

1) The existence of A- and B-type substances as well as O-type substance is proven clearly at about the second month of foetal life.

2) In A- and B-type substances, during the foetal periods, the lower partial antigens are developed far more than the higher partial antigens.

3) In O-type substance, there exists no recognizable difference in development among $\mathrm{O}_{\mathrm{I}}, \mathrm{O}_{\mathrm{II}}$ and $\mathrm{O}_{\mathrm{III}}$ partial antigens.

4) During the first half of the foetal period, the development 
of $\mathrm{O}$-substance is most striking, that of B-substance is less and that of A-substance is least.

5) A-, B- and O-substances all continue to develop from the foetal period, though their velocities may vary, and reach 50-70\% of the adult value at parturition. Their development continues thereafter and the values come close to that of the adult at 5-7 years of age.

\section{References}

1) Mizutani, S.: Juzenkai Zasshi, 37, 2571 (1932).

2) Yamazaki, T.: Chiba Igakkai Zasshi, 11, 59 (1932).

3) Dahr, P. and Lindau, H.: Z. f. Immun. Forschg., 91, 211-226 (1937).

4) Hirota, T.: Hokkaido Igaku Zasshi, 4, 671-680 (1938).

5) Murakami, Y.: Tokyo Igakkai Zasshi, 56, 1 (1942).

6) Sakuma, F.: Hanzaigaku Zasshi, 16, 172-180 (1942).

7) Kobayashi, T.: Tokyo Igakkai Zasshi, 56, 381 (1942).

8) Yamaguchi, K.: Tokyo Igakkai Zasshi, 57, 180 (1943).

9) Friedenreich, V. and With, S.: Z. f. Immun. Forschg., 78, 152-172 (1933).

10) Schiff, F. and Adelsberger, F.: Z. f. Immun. Forschg., 18, 34-68 (1924).

11) Mizu, M.: Juzenkai Zasshi, 36, 4 (1931).

12) Terajima, M.: Tokyo Igakkai Zasshi, 52, 6-53 (1942).

13) Brockmann, H.: Z. f. Immun. Forschg., 9, 87-116 (1911).

14) Inouye, Y.: Tokyo Igakkai Zasshi, 57, 1 (1943).

15) Akimitsu, S.: Hanzaigaku Zasshi, 16, 6 (1942).

16) Ino, S.: Jap. J. Legal Medicine, 4, 59-81 (1950).

17) Kemp, J. and Worsaae, E.: Acta Pathol. et Microbiol. Scand., 8, 71 (1931). 